Journal of Applied Pharmaceutical Science Vol. 7 (07), pp. 055-061, July, 2017

Available online at http://www.japsonline.com

DOI: $10.7324 /$ JAPS.2017.70710

ISSN 2231-3354 (cc)) BY-NC-SA

\title{
In silico Assessment of the Genotypic Distribution of Virulence and Antibiotic Resistance Genes in Pseudomonas aeruginosa
}

\author{
Nusrat Nahar ${ }^{*}$, Sharmeen Asad, Tufael Ahmed, Nurul Islam Setu, Md. Shahidulla Kayser, Md. Shariful Islam, Md. Kamrul \\ Islam, Muhammed Mahfuzur Rahman, D. A. Anwar Al Aman, Ridwan Bin Rashid \\ Computational Chemistry and Bioinformatics Laboratory, Department of Pharmacy, State University of Bangladesh, Dhaka, Bangladesh.
}

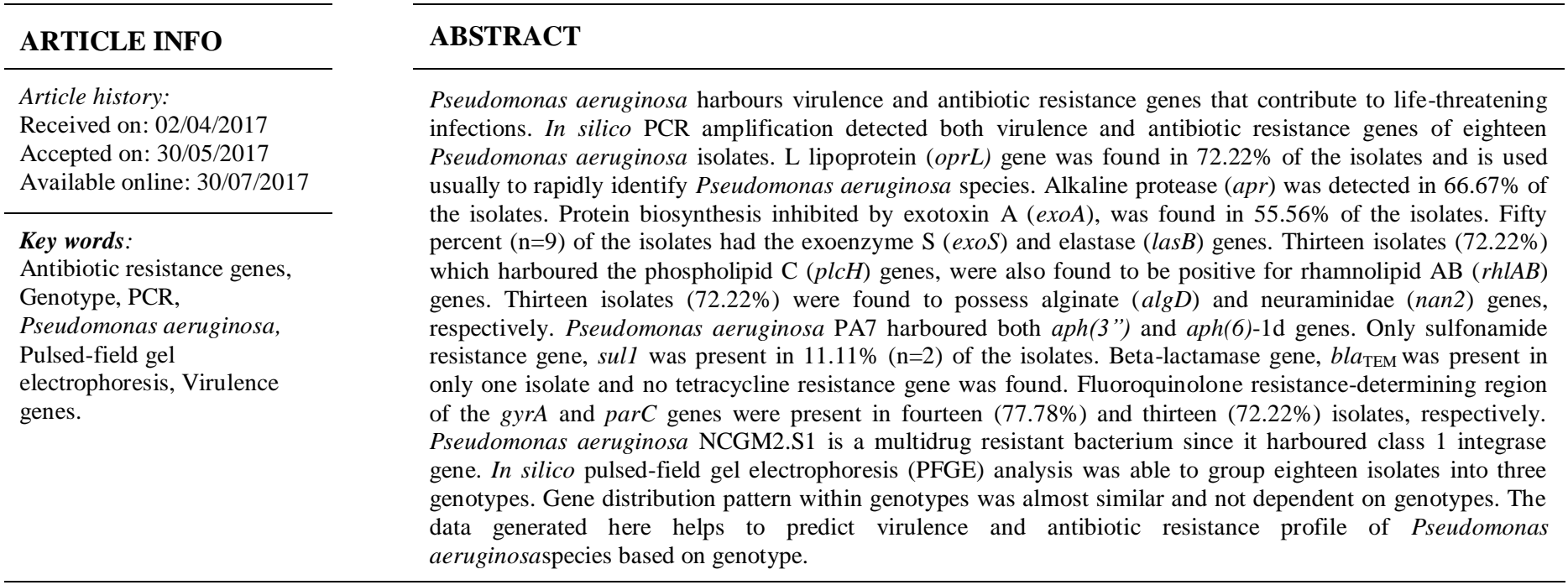

\section{INTRODUCTION}

Pseudomonas aeruginosa is a gram-negative opportunistic pathogen that infects virtually all tissues. Fegan et al. (1990) reported that $P$. aeruginosa is colonized on respiratory tract and contributed to cystic fibrosis infection. Yetkin et al. (2006) reported that $P$. aeruginosa is responsible for nosocomial infection and affects patients in intensive care units. Pollack (2000) stated that immunocompromised cancer patients, burn

\section{Corresponding Author}

Nusrat Nahar, Computational Chemistry and Bioinformatics Laboratory, Department of Pharmacy, State University of Bangladesh, Dhaka, Bangladesh. Email: nusratnahar17 @ gmail.com. patients and catheterized patients also suffer from serious infections that are caused by $P$. aeruginosa. Trautner and Darouiche (2004) reported that biofilms developed by $P$. aeruginosa are attached to the site of infection and caused chronic and recurrent infections. Pseudomonas is responsible for waterborne outbreaks of dermatitis, conjunctivitis and otitis media (Adesoji et al., 2015). Van Delden and Iglewski (1998) stated that virulence properties of $P$. aeruginosa are tightly regulated by cell to cell signaling systems. Virulence factors of $P$. aeruginosa are divided into specific groups such as adhesins or other secreted exotoxins. Bradbury et al. (2010) reported that type I (TISS), type II (T2SS) or type III (T3SS) secretion system actively secreted exotoxins. Bradbury et al. (2010) also stated that previous studies have found the association of virulence factors with different diseases. 
Protein synthesis inhibiting exotoxin A was reported earlier by Thamir and Al-Jubori (2014). Khattab et al. (2015) demonstrated that PCR based amplification of L lipoprotein (oprL) is used for identification of the species of Pseudomonas. Pollack (2000) demonstrated that multidrug-resistant $P$. aeruginosa is medically important and caused several infections. Antibiotic resistance genes can be transferred between different microorganisms with the help of integrase gene, intl (Adesoji et al., 2015). Yah et al. (2006), Bonomo and Szabo (2006), Chen et al. (2009) reported that plasmids or transposons also contributed to developing multidrug-resistant Pseudomonas.

Strateva and Yordanov (2009) concluded that risk factors identification for multidrug-resistant Pseudomonas is important to minimize this problem. Several clinical studies are needed to minimize severe infections caused by Pseudomonas and maximize the outcomes in the treatment of infectious diseases. The aim of the present study is to characterize the virulence and antibiotic resistance property of 18 Pseudomonas aeruginosa isolates by PCR and to find the distribution in genotypes based on pulsed field gel electrophoresis (PFGE).

\section{MATERIALS AND METHODS Strains used in the study}

Strains used in the study are summarized in Table 1.

\section{Primer used in the study}

Primer used for virulence and antibiotic resistance gene detection in the study are summarized in Table 2 and 3.

\section{PCR amplification}

In silico PCR amplification was done in the website http://insilico.ehu.eus/PCR/ (San Millán et al., 2013; Bikandi et al., 2004).

\section{PFGE digestion}

Pulsed field gel electrophoresis (PFGE) digestion was done in the website http://insilico.ehu.es/digest/ (San Millán et al., 2013; Bikandi et al., 2004). The enzyme used for the digestion was PacI. Banding patterns were scored in a binary matrix and a dendrogram was constructed using Complete Linkage method by SPSS 16 (IBM, USA).

Table 1: Name of the isolates.

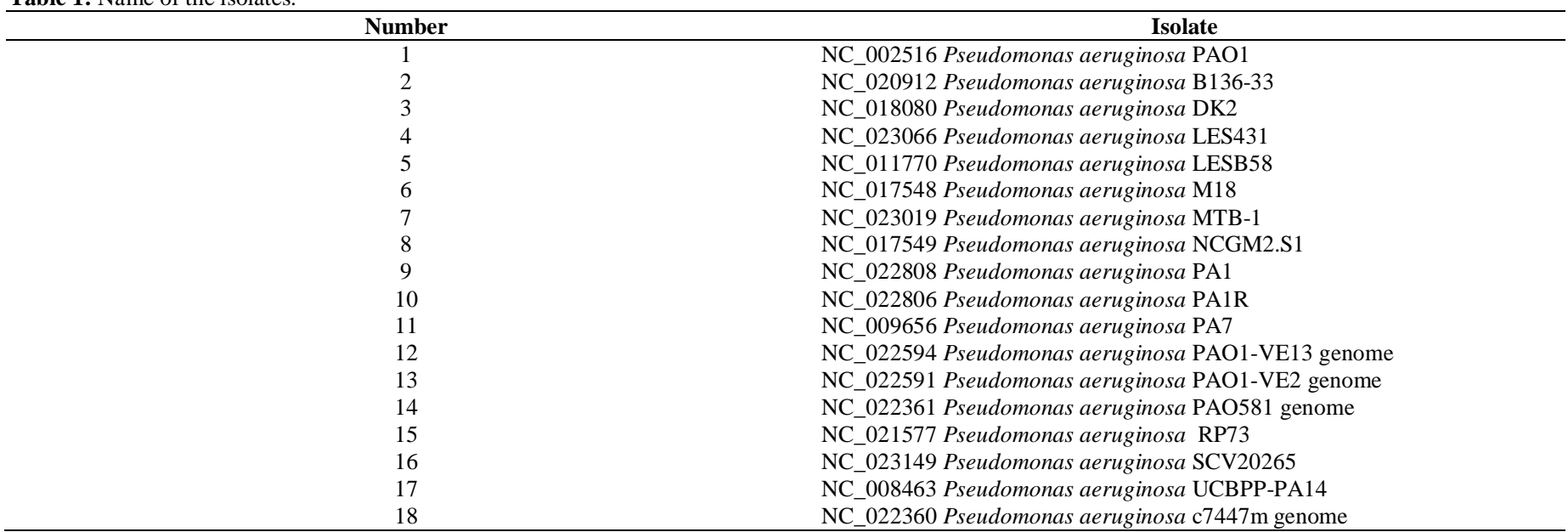

Table 2: Primer for virulence gene detection.

\begin{tabular}{|c|c|c|c|c|}
\hline Target & Gene & Primer & $\begin{array}{l}\text { Amplicon } \\
\text { Size bp }\end{array}$ & Reference \\
\hline L lipoprotein & oprL & $\begin{array}{l}\text { ATG GAAATGCTGAAATTCGGC } \\
\text { CTTCTTCAGCTCGACGCGACG }\end{array}$ & 504 & De Vos et al., 1997 \\
\hline Alkaline protease & apr & $\begin{array}{l}\text { TGTCCAGCAATTCTCTTGC } \\
\text { CGTTTTCCACGGTGACC }\end{array}$ & 1017 & Fazeli and Momtaz, 2014 \\
\hline Exotoxin A & toxA & $\begin{array}{l}\text { GGAGCGCAACTATCCCACT } \\
\text { TGGTAGCCGACGAACACATA }\end{array}$ & 250 & Sabharwal et al., 2014 \\
\hline Exoenzyme $\mathrm{S}$ & $\operatorname{exoS}$ & $\begin{array}{l}\text { CTTGAAGGGACTCGACAAGG } \\
\text { TTCAGGTCCGCGTAGTGAAT }\end{array}$ & 504 & Stover et al., 2000 \\
\hline Elastase & $\operatorname{las} B$ & $\begin{array}{l}\text { GGAATGAACGAAGCGTTCTCCGAC } \\
\text { TGGCGTCGACGAACACCTCG }\end{array}$ & 283 & Fazeli and Momtaz, 2014 \\
\hline Rhamnolipid AB & $\operatorname{rhl} A B$ & $\begin{array}{l}\text { TCATGGAATTGTCACAACCGC } \\
\text { ATACGGCAAAATCATGGCAAC }\end{array}$ & 151 & Sabharwal et al., 2014 \\
\hline Phospholipase C & plcH & $\begin{array}{l}\text { GAAGCCATGGGCTACTTCAA } \\
\text { AGAGTGACGAGGAGCGGTAG }\end{array}$ & 307 & Sabharwal et al., 2014 \\
\hline Alginate & $\operatorname{alg} D$ & $\begin{array}{l}\text { ATGCGAATCAGCATCTTTGGT } \\
\text { CTACCAGCAGATGCCCTCGGC }\end{array}$ & 1311 & Stover et al., 2000 \\
\hline Putative neuraminidase & nan2 & $\begin{array}{l}\text { ACAACAACGGGGACGGTAT } \\
\text { GTTTTGCTGATGCTGGTTCA }\end{array}$ & 1161 & Stover et al., 2000 \\
\hline
\end{tabular}


Table 3: Primer for antibiotic resistance gene detection.

\begin{tabular}{|c|c|c|c|c|}
\hline Target & Gene & $\begin{array}{c}\text { Primer sequence } \\
\left(5^{\prime}-3^{\prime}\right)\end{array}$ & $\begin{array}{c}\text { Amplicon size } \\
\text { bp }\end{array}$ & Reference \\
\hline Class 1 integrase gene & intl & $\begin{array}{l}\text { CCTCCCGCACGATGATC } \\
\text { TCCACGCATCGTCAGGC }\end{array}$ & 270 & Houang et al., 2003 \\
\hline Class 2 integrase gene & int 2 & $\begin{array}{l}\text { TTATTGCTGGGATTAGGC } \\
\text { ACGGCTACCCTCTGTTATC }\end{array}$ & 233 & Roe et al., 2003 \\
\hline Variable region of class 1 integron & $v t 1$ & $\begin{array}{l}\text { GGCATCCAAGCAGCAAG } \\
\text { AAGCAGACTTGACCTGA }\end{array}$ & Variable & Hall and Collis, 1995 \\
\hline Variable region of class 1 integron & $v t 2$ & $\begin{array}{l}\text { CGGGATCCCGGACGGCATGCACGATTTGTA } \\
\text { GATGCCATCGCAAGTACGAG }\end{array}$ & Variable & White et al., 2001 \\
\hline Sulfonamide resistance gene & sull & $\begin{array}{l}\text { CGGCGTGGGCTACCTGAACG } \\
\text { GCCGATCGCGTGAAGTTCCG }\end{array}$ & 433 & Vinue et al., 2010 \\
\hline Sulfonamide resistance gene & sul2 & $\begin{array}{l}\text { GCGCTCAAGGCAGATGGCATT } \\
\text { GCGTTTGATACCGGCACCCGT }\end{array}$ & 293 & Vinue et al., 2010 \\
\hline Sulfonamide resistance gene & sul3 & $\begin{array}{l}\text { TCAAAGCAAAATGATATGAGC } \\
\text { TTTCAAGGCATCTGATAAAGAC }\end{array}$ & 787 & Vinue et al., 2010 \\
\hline Streptomycine resistance gene & $\operatorname{aph}(3 ")$ & $\begin{array}{l}\text { GCTCAAAGGTCGAGGTGTGG } \\
\text { CCAGTTCTCTTCGGCGTTAG }\end{array}$ & 515 & van Overbeek et al., 2001 \\
\hline Streptomycine resistance gene & $a p h(6)-1 d$ & $\begin{array}{l}\text { GACTCCTGCAATCGTCAAGG } \\
\text { GCAATGCGTCTAGGATCGAG }\end{array}$ & 560 & van Overbeek et al., 2001 \\
\hline Streptomycine resistance gene & ant (3") & $\begin{array}{l}\text { CAGCGCAATGACATTCTTGC } \\
\text { GTCGGCAGCGACATCCTTCG }\end{array}$ & 294 & van Overbeek et al., 2001 \\
\hline Tetracycline resistance gene & $\operatorname{tet}(A)$ & $\begin{array}{l}\text { TTGGCATTCTGCATTCACTC } \\
\text { GTATAGCTTGCCGGAAGTCG }\end{array}$ & 494 & Call et al., 2003 \\
\hline Tetracycline resistance gene & $\operatorname{tet}(B)$ & $\begin{array}{l}\text { CAGTGCTGTTGTTGTCATTAA } \\
\text { GCTTGGAATACTGAGTGTAA }\end{array}$ & 571 & Call et al., 2003 \\
\hline Tetracycline resistance gene & $\operatorname{tet}(M)$ & $\begin{array}{l}\text { ATTTCCGCAAAGTTCAGACG } \\
\text { CCGTCATGCAATTTGTGTTC }\end{array}$ & 536 & Call et al., 2003 \\
\hline Beta lactamase gene & $b l a_{\mathrm{TEM}}$ & $\begin{array}{l}\text { AAAGATGCTGAAGATCA } \\
\text { TTTGGTATGGCTTCATTC }\end{array}$ & 425 & Henriques et al., 2006 \\
\hline Beta lactamase gene & $b l a_{\mathrm{SHV}}$ & $\begin{array}{l}\text { GCGAAAGCCAGCTGTCGGGC } \\
\text { GATTGGCGGCGCTGTTATCGC }\end{array}$ & 538 & Henriques et al., 2006 \\
\hline DNA gyrase & gyrA & $\begin{array}{l}\text { GTGTGCTTTATGCCATGAG } \\
\text { GGTTTCCTTTTCCAGGTC }\end{array}$ & 287 & Gorgani et al., 2009 \\
\hline Topoisomarase IV & $\operatorname{parC}$ & $\begin{array}{l}\text { CATCGTCTACGCCATGAG } \\
\text { AGCAGCACCTCGGAATAG }\end{array}$ & 267 & Gorgani et al., 2009 \\
\hline
\end{tabular}

\section{RESULTS AND DISCUSSION}

Eighteen isolates were subjected to pulsed-field gel electrophoresis (PFGE) analysis with Pacl restriction digestion. The recognition sequence of $P a c l$ restriction digestion was TTA_AT'TAA. Twenty-five distinct band sizes were observed upon gel electrophoresis. The banding patterns were converted to binary data and this data can be interpreted by SPSS software to form a dendrogram (Fig. 1).

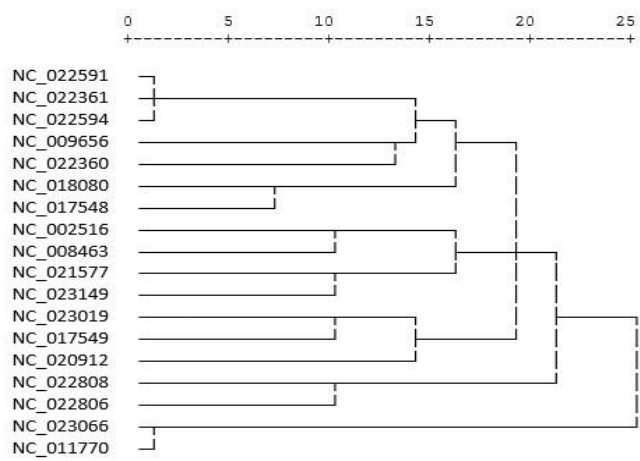

Fig. 1: Phylogenetic diversity of Pseudomonas aeruginosa identified by PFGE.

It was able to group the 18 isolates into 3 genotypes at $20 \%$ dissimilarity cutoff value. Genotype 1 was more prevalent
(77.7\%) (Fig. 2). Genotype 2 and genotype 3 were found to contain $11.11 \%$ of the isolates.

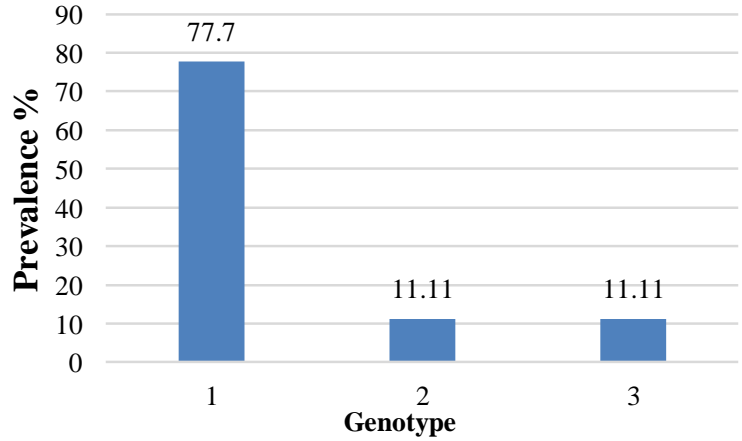

Fig. 2: Prevalence of genotypes.

Virulence factors of Pseudomonas spp. tightly regulated by cell to cell signaling systems was reported by Van Delden and Iglewski (1998). Total eighteen isolates were studied for virulence and antibiotic resistance genes. Out of eighteen isolates, 13 isolates had the L lipoprotein (oprL) with 504 bp gene product. de Vos et al. (1999), Masuda et al. (1995) and Nikaido (1994) previously described that $P$. aeruginos $a$ contained outer membrane protein $\mathrm{L}($ oprL) that is responsible for inherent resistance to antibiotics and antiseptics. This oprL gene is used as a marker for 
rapid identification of $P$. aeruginosa species. According to previous studies (Pitt, 1998; Engel, 2003) collagen, C1q and C3 of the complement pathway, serum protease inhibitors, fibrin, fibrinogen, laminen and elastin are the substrates of alkaline protease, apr. Twelve isolates were found to possess apr gene and produce 1017 bp gene product. Hence the prevalence was 55.56\%. Genotypic distributions were similar in genotype 2 and 3 (Fig. 3). All the isolates present in genotype 2 and 3 harboured oprL and apr genes (100\%). Gene distribution patterns were different in genotype 1 and $64.29 \%$ and $57.14 \%$ present in genotype 1 carried $o p r L$ and $a p r$ genes, respectively.

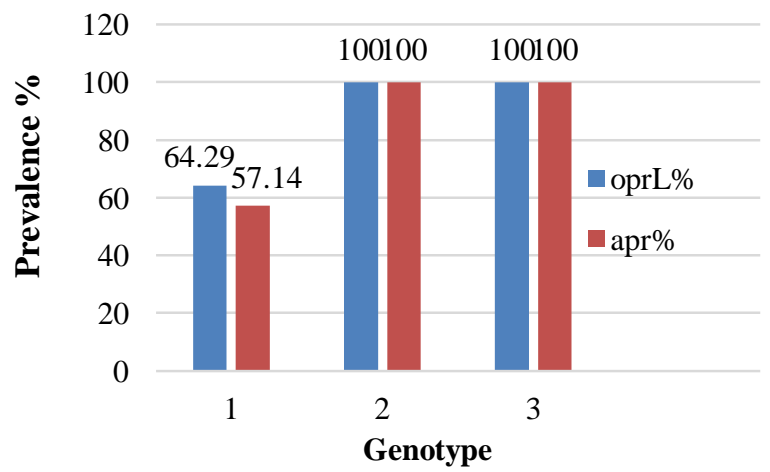

Fig. 3: Genotypic distribution of oprL and apr genes.

Sabharwal et al. (2014) identified that only P. aeruginosa contained exotoxin A (toxA) gene, whereas other species of this genus did not yield toxA gene. Out of the 18 isolates, 10 (55.56\%) isolates had the exotoxin A genes (toxA) with an approximate length of 250 bp. Hamood (2004) reported that protein biosynthesis is inhibited by the action of exotoxin A (toxA). Nikbin et al. (2012) described that toxA gene was found in $90.7 \%$ $P$. aeruginosa isolated from burn, wound and pulmonary tract infections sample. According to Riese et al. (2002) and Anthonv et al. (2007), type-III secretion system directly secrete exoenzyme $S$ (exoS) into the cytosol of human epithelial cell and other studies (Olson et al., 1999; Yahr et al., 1996) found that this inactivated cellular function, inhibited DNA synthesis and microvillus effacement. Nine isolates were found to possess exoenzyme $\mathrm{S}$ (exoS) and gave $504 \mathrm{bp}$ gene product. So, the percentage of prevalence was 50. Recently, Thamir and Jubori (2014) described that $e x o S$ gene was present in higher number in samples collected from cystic fibrosis patients, wound, urine and blood than from sputum and bronchial washer. The $283 \mathrm{bp}$ gene product of las $B$ gene was found in nine isolates. Hence the prevalence was $50 \%$. Sabharwal et al. (2014) reported that elastin, collagen, fibronectin and laminin are substrates of T2SS secreted proteolytic enzyme, las $B$ gene. Elastase, las $B$ gene showed elastolytic activity on human lung tissue and was reported by Lomholt et al. (2001). Phospholipase $\mathrm{C}(\mathrm{plcH})$ hydrolyzing phospholipid was reported by Sabharwal et al. (2014). The plcH gene produces $307 \mathrm{bp}$ gene product and 13 isolates (72.22\%) were found to express $\mathrm{plcH}$ genes. Proinflammatory activities and pulmonary inflammation caused by phospholipase $\mathrm{C}$ ( $\mathrm{plcH}$ ) was reported by Wieland et al. (2002). Terada et al. (1999) examined that oxidative burst of neutrophils is also inhibited by phospholipase $\mathrm{C}(\mathrm{plcH})$. Genotypic distribution of exotoxin A (toxA), exoenzyme $\mathrm{S}$ (exoS), elastase (las $B$ ) and phospholipase $\mathrm{C}(\mathrm{plcH})$ gene was similar in genotype 2 and 3 (Fig. 4). All the isolates present in genotype 2 and 3 harboured these four genes (100\%). Low prevalence of exoS and lasB gene were encountered in genotype $1(35.71 \%)$ while $42.86 \%$ and $64.29 \%$ isolates present in genotype 1 contained toxA and $\mathrm{plcH}$ genes, respectively.

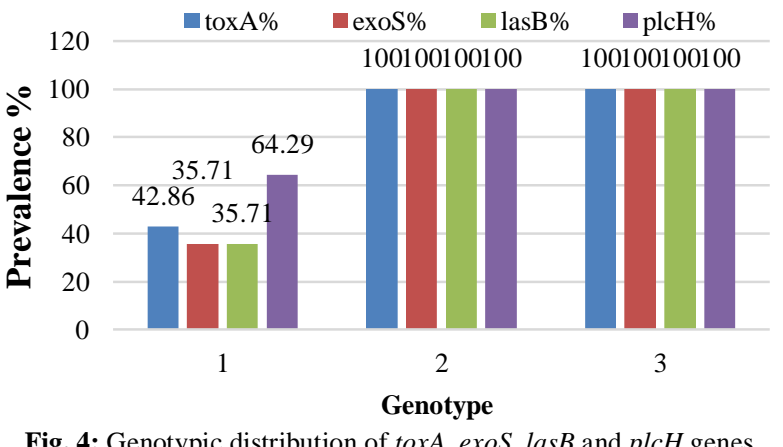

Isolates were also screened for rhamnolipid $\mathrm{AB}($ rhlAB), alginate $(\operatorname{alg} D)$ and putative neuraminidase (nan2). Isolates those harboured $\mathrm{plcH}$ genes were also found to be positive for rhamnolipid $\mathrm{AB}(r h l A B)$ gene. The rhlAB gene produces $151 \mathrm{bp}$ gene product. Van and Iglewski (1998) reported that phospholipids of lung surfactant are solubilized by rhamnolipid and this solubilized phospholipid is more easily cleaved by phospholipid C $(\mathrm{plcH})$. Thirteen isolates were found to possess alginate $(\operatorname{alg} D)$ genes and produced $1311 \mathrm{bp}$ gene product. Hence the prevalence was $72.22 \%$. Govan and Deretic (1996) described that chronic pulmonary inflammation is caused by alginate $(\operatorname{alg} D)$ gene. It also helps to escape host immune surveillance and provide protection from antibiotics. Putative neuraminidase (nan2) was found in $72.22 \%$ of the isolates with $1161 \mathrm{bp}$ gene product. Daniel et al. (2007) reported that spreading of $P$. aeruginosa within the host cells is mediated by neuraminidase gene. Neuraminidase also required for implantation of the bacterium was described by Cacalano et al. (1992) and Davies et al. (1999). Genotypic distribution of $\operatorname{rhlAB}, \operatorname{algD}$ and nan2 gene was similar in all genotypes (Fig. 5). All the isolates present in genotype 2 and 3 carried these three genes (100\%) while $64.29 \%$ isolates present in genotype 1 expressed all these three genes.

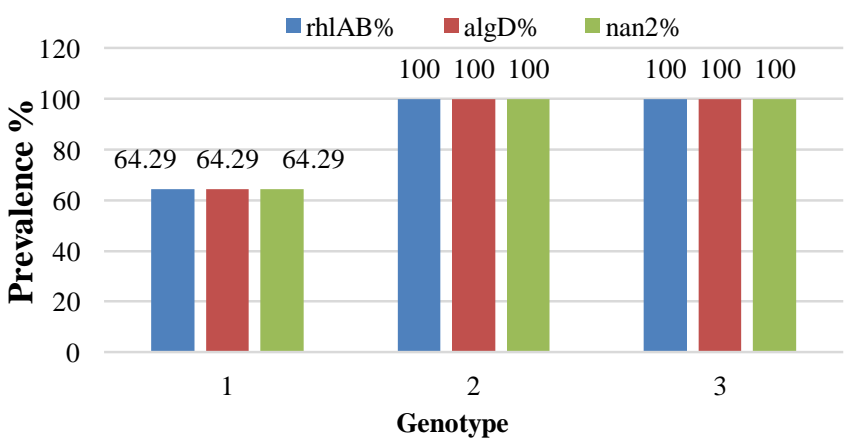

Fig. 5: Genotypic distribution of $r h l A B, \operatorname{alg} D$ and nan2 genes. 
Antibiotic resistance is now a global concern. Isolates were tested for the streptomycin resistance genes. The aph(6)-1d gene produces $560 \mathrm{bp}$ gene product and was present in Pseudomonas aeruginosa PA7. P. aeruginosa PA7 isolate was also found to express $515 \mathrm{bp}$ gene product for aph(3") gene. Only $P$. aeruginosa NCGM2.S1 isolate had the ant(3") gene with 294 bp gene product. So, isolate $P$. aeruginosa PA7 hariboured both aph (3") and aph (6)-1d genes. Adesoji et al. (2015) also reported about a Pseudomonas bacterium that carried more than one streptomycin resistance genes. These isolates had the aminoglycoside modifying enzyme. Llano-Sotelo et al. (2002) reported that antibiotic molecule is modified by AMEs enzyme that linked antibiotic molecule with phosphate, adenyl or acetyl radical. Thus, modified antibiotics could not bind with its target. Aminoglycoside modifying enzyme (AME) genes which includes $\operatorname{aac}\left(6^{\prime}\right)-I$ and ant(2')-I, were found in 50 and $45 \%$ of Pseudomonas isolates, respectively as reported by Odumosu et al. (2003). Seveno et al. (2002) examined that streptomycin resistance is high in clinical and agricultural habitats. Genotype 2 and 3 carried no streptomycin resistance gene (Fig. 6). Gene distribution pattern was similar in genotype 1 and $14 \%$ isolates present in genotype 1 harboured these three genes.

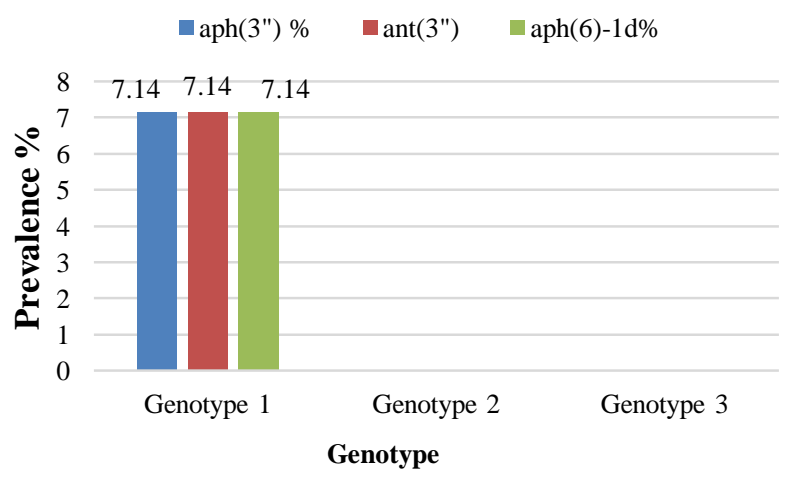

Fig. 6: Genotypic distribution of streptomycin resistance genes.

Sulfonamide resistance gene, sull was present in 2 isolates $(11.11 \%)$ (P. aeruginosa NCGM2.S1, P. aeruginosaPA7) with an amplicon of 433 bp. No isolate harboured the sul2 and sul3 gene. Adesoji et al. (2015) also found sulfonamide resistance gene sull (31.8\%) and no sul3 genes. But their study found sul2 gene $(27.3 \%)$. Only $P$. aeruginosa NCGM2.S1 had the $b l a_{\text {TEM }}$ gene with 425 bp gene product. The $b l a_{\mathrm{SHV}}$ gene was not present in any one of the isolates. Adesoji et al. (2015) found that among the beta lactamase gene, bla $a_{\text {TEM }}$ gene was more prevalent $(40.9 \%)$ than $b^{b l a} a_{\text {SHV }}(27.3 \%)$. Bradford (2001) reported that enterobacteriaceae mainly harboured the enzyme, bla $a_{\mathrm{TEM}}$ and $b l a_{\mathrm{SHV}}$. However, Pseudomonas harboured the $b l a_{\mathrm{TEM}}$ and $b l a_{\mathrm{SHV}}$ gene possibly due to the overuse of beta lactam antibiotics. Adesoji et al. (2015) examined that tetracycline resistance of $\operatorname{tet}(A), \operatorname{tet}(B)$, and $\operatorname{tet}(E)$ gene is acquired by efflux pump system and for $\operatorname{tet}(O)$ and $\operatorname{tet}(M)$ gene, resistance mechanism is developed by ribosomal protection. No isolate was found that contained tetracycline resistance $\operatorname{tet}(A)$, tet(B) or tet $(M)$ gene. Zhang et al. (2009) stated that various environmental genera carried the broad host range tetracycline resistance gene tet(A). Shababi et al. (2011) studies found that the prevalence of $\operatorname{tet}(B)$ gene was higher than tet(A)gene of $P$ aeruginosa samples isolated from municipal sewage. Genotype 2 and 3 contained no sulfonamide, sull or beta lactamase $b l a_{\mathrm{TEM}}$ resistance genes (Fig. 7). The sull and bla $a_{\text {TEM }}$ genes were present in $14.29 \%$ and $7.14 \%$ isolates in genotype 1 .

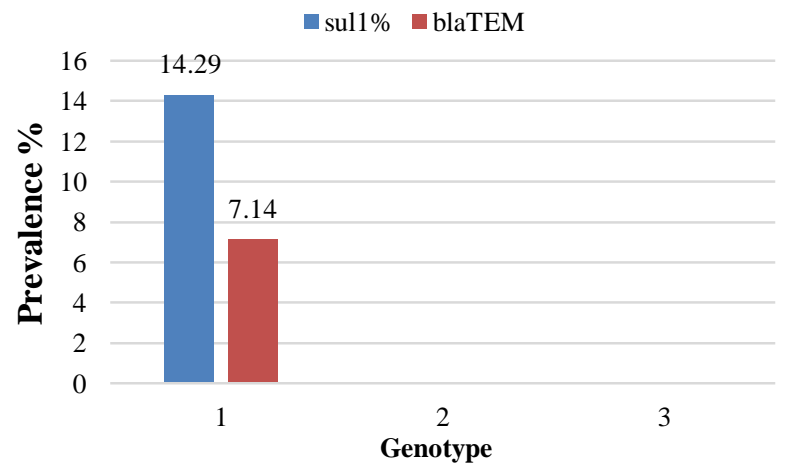

Fig. 7: Genotypic distribution of sull and bla $a_{\text {TEM }}$ genes.

Fazeli and Momtaz (2014) demonstrated that multiplex PCR assays were used to detect fluoroquinolone resistancedetermining region of the gyrA and parC gene. Fourteen isolates were found to express gyrA genes with an approximate length of $287 \mathrm{bp}$. So, the percentage of prevalence was 77.78. Strateva and Yordanov (2009) described that gyrA gene is modified within the enzyme's active site, quinolone-resistant-determinative region by a point mutation and changed the amino acid sequence of $\mathrm{A}$ and $\mathrm{B}$ subunits. This alteration created low affinity quinolone molecules. PCR amplification of parC gene produces 267 bp gene product. Thirteen isolates $(72.22 \%)$ had the parC genes. All the isolates present in genotype 2 and 3 carried gyrA and parC genes (100\%) (Fig. 8). Genotype 1 also harboured gyrA and parC genes and $71.43 \%$ and $64.3 \%$ isolates present in genotype 1 expressed gyrA and $\operatorname{par} C$ genes, respectively.

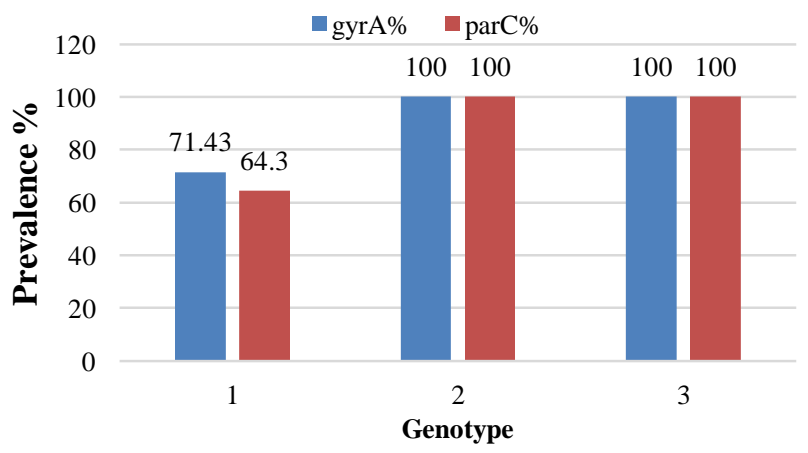

Fig. 8: Genotypic distribution of $g y r A$ and $\operatorname{parC}$ genes.

Class 1 integrase, int 1 was found in only isolate Pseudomonas aeruginosa NCGM2.S1. No isolate was found to harbour class 2 integrase, int2. Mazel (2006), Rowe-Magnus and Mazek (2002) studied class 1 integrase and described that class 1 integrase facilitate the ability to shuttle antibiotic resistance genes 
between different bacterial species. Isolates $P$. aeruginosa NCGM2.S1 contained class 1 integron gene and is considered as a multidrug resistant bacterium. Variable region of class 1 integron was found in one isolate ( $P$. aeruginosa NCGM2.S1). Adesoji et al. (2015) concluded that the variable region of class 1 integrase helps to insert antibiotic resistant cassette in the integrase sequence. Class 1 integrase and variable region of class 1 integron genes were absent in genotype 2 and 3 (Fig. 9). Genotype 1 harboured similar number of class 1 integrase and variable region of class 1 integron gene $(7.14 \%)$.

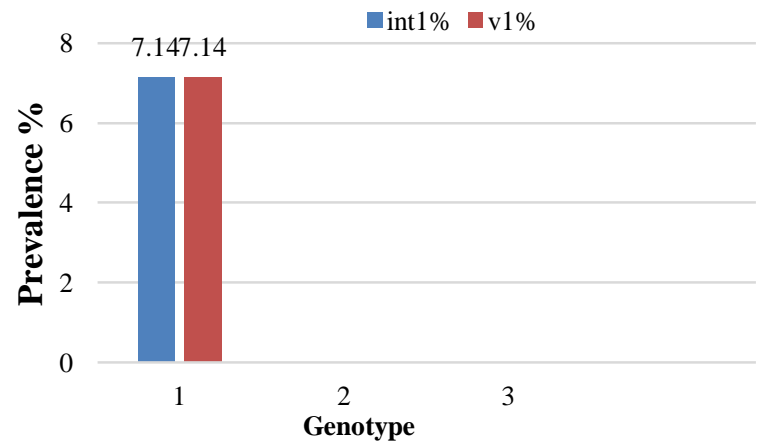

Fig. 9: Genotypic distribution of class 1 integrase and variable region of class 1 integron.

\section{CONCLUSION}

Identification of L lipoprotein, oprL precisely and rapidly identify $P$. aeruginosa species. Gene distribution pattern of virulence and antibiotic resistance genes within genotypes were almost similar. Different virulent genes are identified that may contribute to virulence and pathogenicity of the infections. The data has provided epidemiological information to study the characteristics of the $P$. aeruginosa and also the virulence factors associated with infections. Pseudomonas harbouring class 1 integron spread the antibiotic resistance gene in the environment which is now a global concern. This multidrug resistant Pseudomonas may contribute to many emergence and reemergence infectious diseases. Finally clinical studies are needed to control multidrug-resistant Pseudomonas and maximize the clinical outcomes in the treatment of infectious diseases.

\section{Financial support and sponsorship: Nil.}

Conflict of Interests: There are no conflicts of interest.

\section{REFERENCES}

Adesoji AT, Ogunjobi AA, Olatoye IO. Molecular characterization of selected multidrug resistant Pseudomonas from water distribution systems in southwestern Nigeria. Ann. Clin Microbiol Antimicrob, 2015; 14(1):39.

Anthonv WM, Qing D, Michael SP, Bassam TW, Joseph TB. Pseudomonas aeruginosa exoS ADP-ribosyltransferase inhibits ERM phosphorylation. Cellular Microbiol, 2007; 9(1):97-105.

Bikandi J, San Millán R, Rementeria A, Garaizar J. In silico analysis of complete bacterial genomes: PCR, AFLP-PCR and endonuclease restriction. Bioinformatics, 2004; 20(5):798-799.
Bonomo RA, Szabo D. Mechanisms of multidrug resistance in Acinetobacter species and Pseudomonas aeruginosa. Clin Infect Dis, 2006; 43:49-56.

Bradbury RS, Roddam LF, Merritt A, Reid DW, and Champion AC. Virulence gene distribution in clinical, nosocomial and environmental isolates of Pseudomonas aeruginosa. J Med Microbiol, 2010; 59(8):881890.

century:

Bradford PA. Extended-spectrum beta-lactamases in the $21^{\text {st }}$ characterization, epidemiology, and detection of this important resistance threat. Clin Microbiol Rev, 2001; 14:933-51.

Cacalano G, Kays M, Saiman L, Prince A. Production of the Pseudomonas aeruginosa neuraminidase is increased under hyperosmolar conditions and is regulated by genes involved in alginate expression. J Clin Invest, 1992; 89:1866-1874.

Call DR, Brockman FJ, Chandler DP. Detecting and genotyping Escherichiacoli O157:H7 using multiplexed PCR and nucleic acid microarrays. Int J Food Microbiol, 2003; 67:71-80.

Chen J, Su Z, Liu Y, Wang S, Dai X, Li Y, Peng S, Shao Q, Zhang $\mathrm{H}$, Wen $\mathrm{P}$, Yu J, Huang $\mathrm{X}$, $\mathrm{Xu} \mathrm{H}$. Identification and characterization of class 1 integrons among Pseudomonas aeruginosa isolates from patients in Zhenjiang, China. Int J Infect Dis, 2009; 13:71721.

Daniel GL, Jonathan MU, Gang W, Nicole TL, Rhonda LF, Sachiko M, Lenard TD, Jianxin H, Maude S, Eric D, Lisa F, Li L, George G, Kate M, Raju K, Laurence GR, Frederick MA. Genomic analysis reveals that Pseudomonas aeruginosa virulence is combinatorial. Genome Biol, 2007; 7:R90

Davies J, Dewar A, Bush A, Pitt T, Gruenert D, Geddes DM, Alton EW. Reduction in the adherence ofPseudomonas aeruginosa to native cystic fibrosis epithelium with anti-asialoGM1 antibody and neuraminidase inhibition. Eur Respir J, 1999; 13:565-570.

de Vos D, Lim A, Pirnay JP, Struelens M, Vandenveld C, Duinslaeger L, Vanderkelen A, Cornelis P. Direct detection and identification of Pseudomonas aeruginosa in clinical samples such as skin biopsy specimens and expectorations by multiplex PCR based on two outer membrane genes, oprI and oprL. J Clin Microbiol, 1997; 35:12951299.

Engel JN. 2003.Molecular pathogenesis of acute Pseudomonas aeruginosa infections. In Severe Infections Caused by Pseudomonas aeruginosa, 201-229. Edited by A. R. Hauser \& J. Rello. Dordrecht: Kluwer Academic Publishers.

Fazeli N, Momtaz H. Virulence gene profiles of multidrugresistant Pseudomonas aeruginosa isolated from Iranian hospital infections. Iran Red Crescent Med J, 2014; 16(10):e15722.

Fegan M, Francis P, Hayward AC, Davis GH, Furest JA. Phenotypic conversion of Pseudomonas aeruginosa in cystic fibrosis. J Clin Microbiol, 1990; 28:1143-1146.

Gorgani N, Ahlbrand S, Patterson A, Pourmand N. Detection of point mutations associated with antibiotic resistance in Pseudomonas aeruginosa. Int J Antimicrob Agents, 2009; 34(5):414-8.

Govan JR, Deretic V. Microbial pathogenesis in cystic fibrosis: mucoid Pseudomonas aeruginosa and Burkholderia cepacia. Microbiol Rev, 1996; 60:539-574.

Hall RM, Collis CM. Mobile gene cassettes and integrons: capture and spread of genes by site-specific recombination. Mol Microbiol, 1995; 15:593-600.

Hamood AN, Colmer-Hamood JA, Carty NL. 2004. Regulation of Pseudomonas aeruginosa exotoxin A synthesis. In Pseudomonas: Virulence and gene regulation. Academic/plenum publishers, New York $389-423$.

Henriques IS, Fonseca F, Alves A, Saavedra MJ, Correia A. Occurrence and diversity of integrons and $\beta$-lactamase genes among ampicillin-resistant

isolates from estuarine waters. Res Microbiol, 2006; 157:938-47.

Houang AT, Chu YW, Lo WS, Chu KY, Cheng AF. Epidemiology of rifampin ADP ribosyltransferase (arr-2) and metallo-blactamase (blaIMP-4) gene cassettes in class 1 integrons in Acinetobacter 
strains isolated from blood cultures in 1997 to 2000. Antimicrob Agents Chemother, 2003; 47:1382-90.

Khattab MA, Nour MS, El Sheshtawy NM. Genetic identification of Pseudomonas aeruginosa virulence genes among different isolates. J Microb Biochem Technol, 2015; 7:274-277.

Strateva, T, Yordanov D. Pseudomonas aeruginosa-a phenomenon of bacterial resistance. J Med Microbiol, 2009; 58(9):11331148 .

Llano-Sotelo B, Azucena EF, Kotra LP, Mobashery S, and Chow CS. Aminoglycosides modified by resistance enzymes display diminished binding to the bacterial ribosomal aminoacyl-tRNA site. Chem Biol, 2002; 9:455-463.

Lomholt JA, Poulsen K, Kilian M. Epidemic population structure of Pseudomonas aeruginosa: evidence for a clone that is pathogenic to the eye and that has a distinct combination of virulence factors. Infect Immun, 2001; 69(10):6284-95

Masuda N, Sakagawa E, Ohya S. Outer membrane proteins responsible for multiple drug resistance in Pseudomonas aeruginosa. Antimicrob Agents Chemother, 1995; 39:645-649.

Mazel D. Integrons: agents of bacterial evolution. Nat Rev Microbiol, 2006; 4:608-20.

Nikaido H. Prevention of drug access to bacterial targets: permeability barriers and active efflux. Science. 1994; 264:382-388.

Nikbin VS, Aslani MM, Sharafi Z, Hashemipour M, Shahcheraghi F, Ebrahimipour GH. Molecular identification and detection of virulence genes among Pseudomonas aeruginosa isolated from different infectious origins. Iran J Microbiol, 2012; 4:118-23

Odumosu BT, Adeniyi BA, Chandra R. Analysis of integrons and associated gene cassettes in clinical isolates of multidrug resistant Pseudomonas aeruginosa from Southwest Nigeria. Ann Clin Microbiol Antimicrob, 2013; 12:29-35.

Olson JC, Fraylick JE, McGuffie EM, Dolan KM, Yahr TL, Frank DW, Vincent TS. Interruption of multiple cellular processes in HT29 epithelial cells by Pseudomonas aeruginosa exoenzyme S. Infect Immun, 1999; 67(6):2847-54.

Pitt TL, Pseudomonas, Burkholderia, and related genera. In: Balows A, Duerden BI, eds. Topley and Wilson's Microbiology and Microbial Infections, 1998; 2:1109-1138.

Pollack M. Principles and practice of infectious diseases, eds. In: Mandell, G. L., Bennet, J. E. and Dolin, R. (Churchill Livingstone, Philadelphia), 2000; 2:2310-2335.

Riese MJ, Goehring UM, Ehrmantraut ME, Moss J, Barbieri JT, Aktories K, Schmidt G. Auto-ADP-ribosylation of Pseudomonas aeruginosa. ExoS J Biol Chem, 2010; 277(14):12082-12088.

Roe MT, Vega E, Pillai SD. Antimicrobial resistance markers of Class 1 and Class 2 integron bearing Escherichia coli from irrigation water and sediments. Emerg Infect Dis, 2003; 9:822-6.

Rowe-Magnus DA, Mazel D. The role of integrons in antibiotic resistance gene capture. Int J Med Microbiol, 2002; 292:115-25.

Sabharwal N, Dhall S, Chhibber S, Harjai K. Molecular detection of virulence genes as markers in Pseudomonas aeruginosa isolated from urinary tract infections. Int J Mol Epidemiol Genet, 2014; 5(3):125.

San Millán RM, Martínez-Ballesteros I, Rementeria A, Garaizar J, Bikandi J. Online exercise for the design and simulation of PCR and PCR-RFLP experiments. BMC Res Notes, 2013; 6(1):513.

Seveno NA, Kallifidas D, Smalla K, van Elsas JD, Collard JM, Karagouni

$\mathrm{AD}$,

Wellington EMH. Occurrence of reservoirs of antibiotic resistance genes in the environment. Rev Med Microbiol, 2002; 13:15-27

Shehabi AA, Haider AA, Fayyad MK. Frequency of antimicrobial resistance markers among Pseudomonas aeruginosa and Escherichia coli isolates from municipal sewage effluent water and patients in Jordan. Int Arabic J Antimicrob Agents, 2011; 1:1-5.
Stover CK, Pham XQ, Erwin AL, Mizoguchi SD, Warrener P, Hickey MJ, Brinkman FS, Hufnagle WO, Kowalik DJ, Lagrou M, Garber RL. Complete genome sequence of Pseudomonas aeruginosa PAO1, an opportunistic pathogen. Nature, 2000; 406:959-964.

Strateva Tanya, Daniel Yordanov. Pseudomonas aeruginosa-a phenomenon of bacterial resistance. J Med Microbiol, 2009; 58(9):11331148 .

Terada LS, Johansen KA, Nowbar S, Vasil AI, Vasil ML. Pseudomonas aeruginosa hemolytic phospholipase C suppresses neutrophil respiratory burst activity. Infect Immun, 1999; 67(5):2371-6.

Thamir E, Al-Jubori, SS. Genetic detection of some virulence genes in Pseudomonas aeruginosa isolated from cystic fibrosis and nocystic fibrosis patients in Iraq. J Genet Environ Resour Conserv, 2014; 2(3):380-387.

Trautner BW, Darouiche RO. Role of biofilm in catheterassociated urinary tract infection. Am J Infect Control, 2004; 32:177-183.

Van Delden C, Iglewski BH. Cell-to-cell signaling and Pseudomonas aeruginosa infection. Emerg Infect Dis, 1998; 4:551-560

van Overbeek LSV, Wellington EMH, Egan S, Smalla K, Heuer H, Collard JM, Guillaume G, Karagouni AD, Nikolakopoulou TL, Elsas JDVE. Prevalence of streptomycin-resistance genes in bacterial populations in European habitats. FEMS Microbiol Ecol, 2001; 42:27788.

Vinue L, Saenz Y, Rojo-Bezares B, Olarte I, Undabeitia E, Somalo S, Zarazaga M, Torres C. Genetic environment of sulgenes and characterisation of integrons in Escherichia coli isolates of blood origin in a Spanish hospital. Int J Antimicrob Agents, 2010; 35:492-6.

White PA, Mciver CJ, Rawlinson WD. Integrons and gene cassettes in the Enterobacteriaceae. Antimicrob Agents Chemother, 2001; 45:2658-61.

Wieland CW, Siegmund B, Senaldi G, Vasil ML, Dinarello CA, Fantuzzi G. Pulmonary inflammation induced by Pseudomonas aeruginosa lipopolysaccharide, phospholipase $\mathrm{C}$, and exotoxin A: role of interferon regulatory factor 1. Infect Immun, 2002; 70(3):1352-8.

Yah SC, Eghafona NO, Enabulele IO. Prevalence of plasmids mediated Pseudomonas aeruginosa resistant genes from burn wound patients at the university of Benin teaching hospital Benin City. Nigeria J Biomed Sci, 2006; 5:61-8

Yahr TL, Goranson J, Frank DW. Exoenzyme S of Pseudomonas aeruginosa is secreted by a type III pathway. Mol Microbiol, 1996; 22(5):991-1003.

Yetkin G, Otlu B, Cicek A, Kuzucu C, Durmaz R. Clinical, microbiologic, and epidemiologic characteristics of Pseudomonas aeruginosa infections in a university hospital, Malatya, Turkey. Am J Infect Control, 2006; 34:188-192.

Zhang XX, Zhang T, Fang HHP. Antibiotic resistance genes in water environment. Appl Microbiol Biotechnol, 2009; 82:397-414.

\section{How to cite this article:}

Nahar N, Asad S, Ahmed T, Setu NI, Kayser MS, Islam MS, Islam $\mathrm{MK}$, Rahman MM, Al Aman DAA, Rashid RB. In silico assessment of the genotypic distribution of virulence and antibiotic resistance genes in Pseudomonas aeruginosa. J App Pharm Sci, 2017; 7 (07): 055-061. 